\title{
Luang Phor Thuad: A Faith Network in Southern Thailand
}

\author{
Phrakhru Srijariyaporn $^{1}$, Kla Somtrakool ${ }^{1} \&$ Marisa Koseyayothin $^{2}$ \\ ${ }^{1}$ The Faculty of Cultural Science, Mahasarakham University, Khamriang Sub-District, Kantarawichai District, \\ Maha Sarakham Province, Thailand \\ ${ }^{2}$ Kanchanapisek Non-Formal Education Centre (Royal Academy), Salaya Sub-District, Bhuttamonthon District, \\ Nakhon Pathom Province, Thailand \\ Correspondence: Phrakhru Srijariyaporn, The Faculty of Cultural Science, Mahasarakham University, Khamriang \\ Sub-District, Kantarawichai District, Maha Sarakham Province 44150, Thailand. E-mail: \\ psrijariyaporn142@gmail.com
}

Received: May 6, 2014 Accepted: June 20, 2014 Online Published: June 30, 2014

doi:10.5539/ach.v6n2p52 URL: http://dx.doi.org/10.5539/ach.v6n2p52

\begin{abstract}
This is a qualitative investigation with the aims of studying the current state of the Luang Phor Thuad faith network in Southern Thailand and obstacles to its success. Field research was conducted in three purposively selected provinces on the border between Thailand and Malaysia: Pattani, Yala and Narathiwat. Field data was collected by means of survey, observation, interview, focus group discussion and workshop from a purposively selected sample population of ninety individuals. Results show that modern community belief in Luang Phor Thuad is a result of the supernatural power and grandeur afforded to him by monks. There are four types of belief in Luang Phor Thuad: belief in his holy spirit, belief in his supernatural power, belief in vows and belief in worship. These beliefs are represented in two distinct ways: public and personal. The network of faith in Luang Phor Thuad includes schools, communities, government institutions and temples. Their organization of auspicious activities helps raise funds for temple restoration and maintenance. The largest obstacle when organizing activities associated with Luang Phor Thuad is their nature as a Buddhist religious representation in a predominantly Muslim society.
\end{abstract}

Keywords: Luang Phor Thuad, Buddhism, Islam, faith, network

\section{Introduction}

Intangible power is a popular form of belief among human societies (Chaiyotha, 2003). This power has been worshipped in the guise of Buddhism throughout much of Thailand since the Dvaravati period of history (Piyapan, 1994). The religion has been inherited in many forms but one of the most popular manifestations of respect is the possession of a sacred amulet. In the Southern Thai provinces, these amulets often take the form of Luang Phor Thuad (known as Pra Luang Bu Thuad in other provinces). Luang Phor Thuad was a revered monk who has earned deep and lasting respect among Thai Buddhists since his death in 1682, especially those people in the three Southern border provinces. The holiness of Luang Phor Thuad is proved by hearsay or self-encountered experience and his famous powers include protection and safety in times of danger, encouragement of progress at work, promotion of lucrative commercial trade and homage to public charity. These powers benefit the Thai public and foreign visitors through the organization of activities, projects and fund-raising ventures in the name of Luang Phor Thuad.

Despite the benefits of a network of faith in Luang Phor Thuad, there have been a number of obstacles to its success. Unrest in the southern provinces has had a negative impact on education policy, the quality of education, the attitude of people towards the faith of Luang Phor Thuad, the strength of the public sectors, the economy, community relationships, provincial development and the attitude of society towards Buddhist temples and holy objects. This scenario is partly caused by the multicultural nature of Southern Thailand and the high percentage of Muslims in the community. Given these problems, the research team was concerned with assessing the current state of the Luang Phor Thuad faith network in Southern Thailand and the problems it faces.

\section{Methodology}

This is a qualitative investigation with the aims of studying the current state of the Luang Phor Thuad faith network in Southern Thailand and obstacles to its success. Field research was conducted in three purposively 
selected provinces on the border between Thailand and Malaysia: Pattani, Yala and Narathiwat. These provinces were selected due to the mixed society of Buddhist and Muslim people, simmering political tensions and widespread insurgency. Importantly though, this area is the origin of Luang Phor Thuad. Two temples and their surrounding communities were purposively selected from each province: Rat Burana and Sai Kao Temples in Pattani, Mueang Yala and Khok Chang Temples in Yala and Prachapirom and Tung Kha Temples in Narathiwat.

Field data was collected by means of survey, observation, interview, focus group discussion and workshop from a purposively selected sample population of ninety individuals. The basic survey was used to gather general information about the respondents, the communities and the history of the Luang Phor Thuad faith network. The research team then entered the field and performed both participatory and non-participatory observation to study the activities of the Luang Phor Thuad faith network. Respondents were then taken for structured and unstructured interviews to collect data regarding the current state and obstacles to the Luang Phor Thuad faith network. These results were supplemented by information from focus group discussions and concluded at a workshop.

All gathered data was validated using a four step triangulation technique, comprising data triangulation, investigator triangulation, theory triangulation and methodological triangulation. The validated results were then arranged according to the aims of the research and analyzed by analytic induction and typological analysis. The results are here presented as a descriptive analysis.

\section{Results}

Modern community belief in Luang Phor Thuad is a result of the supernatural power and grandeur afforded to him by monks. When he passed away, his corpse was kept in a stupa at Chang Hai Temple, Pattani Province to ensure that people could continue to benefit from his soul. Subsequent rituals associated with the memory of Luang Phor Thuad and supernatural experiences claimed to be caused by his aura have cemented the level of acceptance for his holiness, especially among Buddhist communities in Southern Thailand. The most obvious examples of reverence towards Luang Phor Thuad are the song nam custom of Chang Hai Temple and the creation of Luang Phor Thuad talismans at other temples in the three Southern Thai border provinces.

There are four types of belief in Luang Phor Thuad: belief in his holy spirit, belief in his supernatural power, belief in vows and belief in worship. These beliefs are represented in two distinct ways. Firstly, there are physical and public displays of faith at organized events, via worship or offerings. Secondly, there is more personal, emotional faith that is particular to each individual. There are four ways in which belief in Luang Phor Thuad has been successfully transmitted and represented in other regions, domestically and internationally. These four forms of representation are amulets, worship, replica idols and educational media (Figure 1).

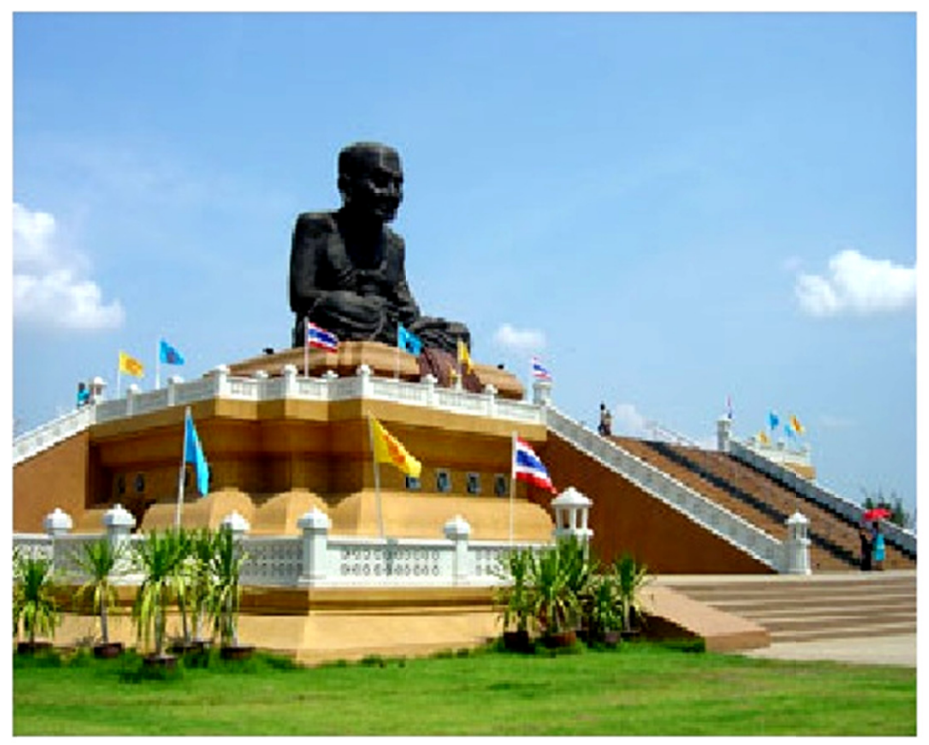

Figure 1. A large replica of Luang Phor Thuad in Huai Mongkon Temple, Prajuab Khirikhan Province 
The network of faith in Luang Phor Thuad includes schools, communities, government institutions and temples. Of these, temples organize events with the clearest link to Luang Phor Thuad. Their organization of auspicious activities helps raise funds for temple restoration and maintenance. The Pattani Provincial Government Institution held events to commemorate Luang Phor Thuad in 2007 and 2012, which helped to raise funds for social welfare projects. Communities are more often associated with private individual belief in Luang Phor Thuad, although the Chang Hai Temple community is responsible for the organization of the annual song nam customs. Schools do not have a direct relationship with the faith network of Luang Phor Thuad because they concentrate more on educational than religious matters. However, they do benefit from donations and funding generated in the name of Luang Phor Thuad.

\subsection{Problems and Obstacles to the Faith Network of Luang Phor Thuad}

The largest obstacle when organizing activities associated with Luang Phor Thuad is their nature as a Buddhist religious representation in a predominantly Muslim society. The three Southern border provinces in Thailand have an 80 percent Muslim population. For this reason, Luang Phor Thuad is not a widely accepted figure of holiness. Additionally, the hostile political situation since 2004 has influenced all aspects of daily life in Southern Thailand, especially community gatherings and religious congregations. Given the disjointed nature of everyday society, there is a lack of education and understanding between religious and social groups regarding the customs of others. For this reason, religious events are viewed as specifically benefitting believers of that religion and unrelated to members of other religious groups. This is the fundamental problem with the organization of activities and a faith network associated with Luang Phor Thuad in the three Southern border provinces of Thailand.

Thirty respondents were asked for suggestions to overcome the stated obstacles and concluded a 'Luang Phor Thuad Fund' as a means for harnessing the strengths of existing faith and ensuring the beliefs and customs might continue to appeal in the future and garner a more dedicated and widespread following. The Luang Phor Thuad Fund has three features: Development of education, development of occupations and development of life skills. Respondents felt that focus on educating young people in the inheritance of traditional customs and culture, as well as respect for alternative traditions and society would help strengthen community spirit and response to Luang Phor Thuad associated activities. Respondents felt that generation of employment opportunities would raise the level of life quality and reduce simmering social conflict, enabling all groups to accept Luang Phor Thuad activities. Respondents felt that by developing life skills that are appropriate for each age-group and gender, society will automatically become more harmonized by the activities required for such development. This will help promote widespread social acceptance.

\section{Discussion}

The similar veneration of Luang Phor Thuad among Buddhist communities in each of the six communities investigated as part of this research is consistent with the symbolic interactionism theory conceptualized by George Herbert Mead (1934) and coined by Herbert Blumer (1969). One part of the concept is that the relationship between humans and their society is derived from the meanings extrapolated by individuals from acts, actions and symbols. These meanings are then inherited from one generation to the next and social constructs are thus formed. This is represented by the influence of contemporary monks in spreading the Luang Phor Thuad faith network. In this case, Luang Phor Thuad is the symbol that exists in each age (Ninbon, 2003; Preeyatikit, 1994), which is in no small part down to the role of Chang Hai Temple as a centre of the Luang Phor Thuad faith network (Wiyot, 2004).

The most difficult obstacle to the Luang Phor Thuad faith network is the poor relationship between Buddhist and Muslim society. This is explained by the balance theory of Fritz Heider (1958). Heider proposed that people like one another if they share similar opinions. Once there is an imbalance, people will try to compromise in order to accommodate the opinions of the other party. This theory emphasizes that similarities between people and groups determines their level of mutual appreciation (Wowen \& Minor, 1998). Belief in Luang Phor Thuad and the good deeds of health, protection and security that he represents are able to transcend religious boundaries and encourage positive behavior promoted by both Buddhism and Islam. Where the relationships between Buddhists and Muslims are good, there remains a lack of understanding and appreciation for other religions. As Rattiya Saleh (2001) concluded, a lack of cultural understanding between two groups of people in the same society has a significant impact on the way of life.

The use of funds generated from Luang Phor Thuad related activities can be and are put to positive use for temple restoration and maintenance and social welfare projects. However, given the precarious administrative situation of the three Southern border provinces, government funding is poorly managed and is not always used 
to the maximum benefit of the population. The faith network of Luang Phor Thuad can help to overcome these problems by creating stronger links within and between communities to better manage the distribution of benefits (Niratorn, 2000). According to the work of Naruemon Niratorn (2000), the benefit of community participation in networks is the opportunity created for members to develop themselves in terms of intelligence, knowledge and problem solving. In this way, community participation is both the means and end of successful networks. However, Pan Kimpee (1997) also indicated the significance of the government, private sector and local business, who must all participate in networks for those networks to have any true and lasting impact.

\section{References}

Blumer, H. (1969). Symbolic Interactionism; Perspective and Method. Englewood Cliffs, NJ: Prentice-Hall.

Chaiyotha, D. (2003). Thai society, culture and customs [in Thai]. Bangkok: Odeon Store.

Heider, F. (1958). The Psychology of Interpersonal Relations. Hoboken, NJ: John Wiley \& Sons. http://dx.doi.org/10.1037/10628-000

Kimpee, P. (1997). Development of extra-curricular knowledge networks for the self-reliance of the community [in Thai]. Bangkok: Chulalongkorn University Press.

Mead, G. H. (1934). In C. W. Morris (Ed.), Mind, Self, and Society. Chicago, IL: University of Chicago Press.

Ninbon, P. (2003). The history and legends of Songkla in the era of the written word, Sathing Phra District (3rd ed.) [in Thai]. Bangkok: Chulalongkorn University Press.

Niratorn, N. (2000). Creation of work networks: A case of needing to examine certain types [in Thai]. Bangkok: Chulalongkorn University Press.

Peeyapan, B. (1994). History of religion in Southeast Asia [in Thai]. Bangkok: Odeon Store.

Preeyatikit, A. (1994). Memorial of the opening ceremony of 60 hospital beds at Khok Pho Hospital [in Thai]. Bangkok: Krung Siam Printing Group.

Saleh, R. (2001). Relationships between people of different religions in Pattani, Yala and Narathiwat [in Thai]. Bangkok: Thailand Research Fund.

Wiyot, P. (2004). The characteristics, motivation, satisfaction and disappointments of people visiting Chang Hai Temple [in Thai]. PhD Thesis, National Institute of Development Administration, Bangkok.

Wowen, J. C., \& Minor, M. (1998). Consumer Behavior (5th ed.). Upper Saddle River, NJ: Prentice-Hall.

\section{Copyrights}

Copyright for this article is retained by the author(s), with first publication rights granted to the journal.

This is an open-access article distributed under the terms and conditions of the Creative Commons Attribution license (http://creativecommons.org/licenses/by/3.0/). 